Piotr Sroczyński ${ }^{1}$

0000-0001-8643-5598

Papieski Wydział Teologiczny we Wrocławiu

\title{
Transcendencja osoby ludzkiej w refleksji filozoficznej kardynała Karola Wojtyły
}

W historii ludzkości człowiek stanowił sam dla siebie wielką zagadkę poznawczą. Prowadzony ciekawością do poznania prawdy o rzeczywistości, wnikał nie tylko w otaczający go świat, ale także badał i zgłębiał tajemnicę ludzkiego bytu. Dzieje filozofii świadczą o tym, że w tej refleksji nad sobą uderzała go i zdumiewała wyraźna odmienność i wyższość nad pozostałymi bytami w przyrodzie i świecie. $W$ antropologicznych rozważaniach wskazywano dość często na podobieństwo człowieka do innych bytów w przyrodzie. Nazywano go mikrokosmosem i uwydatniano jego wyjątkową pozycję w hierarchii bytów istniejących w świecie ${ }^{2}$. Ową wyjątkową bytową pozycję wiązano prawie zawsze z faktem świadomego

1 Ks. Piotr Sroczyński - prezbiter diecezji wrocławskiej, doktor habilitowany nauk teologicznych, katechetyk i pedagog, profesor Papieskiego Wydziału Teologicznego we Wrocławiu. Kierownik Katedry Katechetyki PWT we Wrocławiu; wykłada katechetykę i dydaktykę. W swoich badaniach skupia się m.in. na metodach, środkach, formach stosowanych we współczesnej katechezie polskiej. Członek Stowarzyszenia Katechetyków Polskich. E-mail: mieczducha@poczta.fm.

2 Por. M. Kurdziałek, Średniowieczne doktryny o człowieku jako obrazie świata, „Roczniki Filozoficzne" 19 (1971) z. 1, s. 5-39. 
i wolnego działania człowieka. Dlatego też analizie i wyjaśnianiu ludzkiego działania poświęcano w dziejach filozofii bardzo dużo uwagi.

W dobie współczesnej filozoficzna refleksja nad człowiekiem przybrała na sile. Okazuje się, że przewijające się przez wieki pytanie o człowieka wcale się nie zestarzało, ale jest obecnie szczególnie żywe i aktualne. Pojawiła się niespotykana dotąd liczba publikacji na ten temat. O ile jednak filozoficzny obraz człowieka wypracowany przez starożytność i średniowiecze wyraźnie akcentował stronę duchową bytu ludzkiego, która wskazywała na jego bytowy priorytet wśród bytów ziemskich, o tyle obraz człowieka kreowany przez czasy nowożytne, zwłaszcza współczesne, został pozbawiony tego właśnie wymiaru. Nastąpiło zawężenie prawdy o bycie ludzkim. Wynikało to najczęściej z błędnych założeń danej filozofii lub wyimkowego, fragmentarycznego patrzenia na człowieka. Do wyraźnego okrojenia i spłycenia prawdy o człowieku przyczyniły się niewątpliwie filozofie o profilu scjentystycznym i neopozytywistycznym, różnorakie antysystemowe filozofie podmiotu oraz marksizm. Zawężona wizja człowieka stworzyła ogromne zagrożenie dla racjonalnych wartości humanistycznych i doprowadziła do tworzenia kultury, w której człowiek stawał się przedmiotem różnorodnych manipulacji i bywał redukowany do roli narzędzia. $\mathrm{W}$ takiej sytuacji zrodził się, w pewnych środowiskach intelektualnych, postulat odczytania na nowo obiektywnej i zarazem integralnej prawdy o człowieku i o całej rzeczywistości. Obudziła się świadomość, że rezygnacja z dawnej, klasycznej filozofii, usiłującej poznać i definitywnie wyjaśnić rzeczywistość (w tym także i człowieka), stanowi ogromną szkodę wyrządzoną jemu i kulturze. Te przesłanki znalazły się u źródeł ukształtowania się w naszym kraju, w środowisku Katolickiego Uniwersytetu Lubelskiego, po drugiej wojnie światowej, tak zwanej lubelskiej szkoły filozoficznej, zwanej inaczej polską szkołą filozofii klasycznej lub szkołą lubelską ${ }^{3}$. Szkoła ta wypracowała obiektywną i zarazem integralną filozofię człowieka jako bytu osobowego. Jest ona oparta na doświadczeniu historycznym (doświadczenie najlepszych myślicieli przeszłości i teraźniejszości, ze św. Tomaszem z Akwinu na czele) i spełnia wymogi współczesnej

3 Zob. M. A. Krąpiec, Człowiek. Kultura. Uniwersytet, Lublin 1982. 
metodologii filozofii; jest osadzona głęboko w glebie metafizyki klasycznej. Właśnie w tej szkole został bardzo czytelnie uwydatniony rys transcendencji człowieka wobec innych bytów w przyrodzie, rys, na który wskazywali już dawni mistrzowie myślenia filozoficznego, a który został poznany przez wiele kierunków filozofii współczesnej.

Do twórców lubelskiej szkoły filozoficznej należał kardynał Karol Wojtyła. Reprezentował tzw. tomizm fenomenologizujący ${ }^{4}$. Postawił sobie za cel, zwłaszcza w ostatnim okresie swojej filozoficznej działalności, dokonanie swego rodzaju syntezy klasycznej (głównie Tomaszowej) filozofii bytu i filozofii podmiotu (świadomości). Wojtyła chciał, aby metafizyczne sposoby interpretacji ludzkiej osoby i jej działania zasymilowały te prawdy o człowieku i o jego czynach, które dostępne są poznaniu filozoficznemu przy zastosowaniu metody fenomenologicznej. Realizacja tego zamierzenia, uwidoczniona w jego publikacjach z zakresu etyki i antropologii filozoficznej z lat 1951-1978, przyniosła bardzo interesujące i oryginalne efekty. Propozycja Wojtyły, zwłaszcza po powołaniu go na stanowisko namiestnika Chrystusowego, wzbudziła w wielu kręgach intelektualnych świata wielkie zainteresowanie. Owo zainteresowanie rozszerzyło się poniekąd na całą filozofię uprawianą w szkole lubelskiej.

Centralną ideą filozoficznej wizji człowieka, która przewija się w myśli kard. Karola Wojtyły, jest transcendencja osoby w czynie. Krakowski kardynał odważył się powiedzieć: „transcendencja jest jakby drugim imieniem osoby" 5 . Ta właśnie centralna idea transcendencji godna jest rozważenia, tym bardziej wydaje się ona szczególnie ważna dla współczesnej kultury. Główny problem wykładu zawarty będzie w pytaniu: w jaki sposób została odczytana przez Wojtyłę prawda o transcendencji bytu ludzkiego, jak jest rozumiana, w jaki sposób zaprezentowana i jak zinterpretowana?

Zasadniczym źródłem do przedstawienia zagadnienia transcendencji osoby w ujęciu kard. Wojtyły, będzie jego główne dzieło antropologiczne Osoba i czyn (Kraków 1969), a także studium etyczne

\footnotetext{
4 A. B. Stępień, Fenomenologia tomizująca w ksiażce „Osoba i czyn”, ,Analecta Cracoviensia” 5-6 (1973-1974), s. 155.

5 K. Wojtyła, Osoba: podmiot i wspólnota, „Roczniki Filozoficzne” 24 (1976) z. 2, s. 15, 17.
} 
Mitość i odpowiedzialność (Lublin 1982). Ponadto będą uwzględnione jego ważniejsze artykuły podejmujące interesującą nas problematykę napisane do roku 1978, a także dyskusja nad książką Osoba i czyn, jaka odbyła się na KUL-u 16 grudnia 1970 roku w gronie profesorów i wykładowców filozofii z wielu ośrodków teologicznych naszego kra$\mathrm{ju}^{6}$. Dyskusja ta, poszerzona o dodatkowe wypowiedzi, została opublikowana w „Analecta Cracoviensia” 5-6 (1973-74). Była to pierwsza intelektualna reakcja dwudziestu czołowych postaci polskiej intelektualnej elity katolickiej na dzieło księdza kardynała. Literatura filozoficzna poświęcona dorobkowi filozoficznemu i teologicznemu Karola Wojtyły niepomiernie wzrosła po roku 1978, a więc po jego wyniesieniu na Stolicę Piotrową.

\section{Człowiek i jego doświadczenie}

Doświadczenie, zdaniem Wojtyły, jest kanałem poznawczym odkrywającym transcendencję człowieka. Człowiek, doświadczając siebie samego, doświadcza zarazem swojej wyższości i odmienności w świecie natury. Doświadczenie wiąże się każdorazowo z określoną dziedziną faktów, wśród których szczególnym jest człowiek wraz ze swoim działaniem. Jest ono kontaktem poznawczym z przedmiotem i dzięki temu zachowuje charakter przedmiotowy. W każdym ludzkim doświadczeniu uczestniczą zarazem zmysły i intelekt. Każde ludzkie doświadczenie jest również jakimś zrozumieniem tego, czego się doświadcza. W integralnym doświadczeniu człowieka, według Wojtyły, zawarte jest wewnętrzne doświadczenie samego siebie, doświadczenie własnej zewnętrzności, cudzej zewnętrzności oraz cudzego wnętrza. Na szczególne wyróżnienie zasługuje, $w$ tych odmianach, doświadczenie wewnętrzne samego siebie wraz z moralną kwalifikacją czynów. Interpretacja danych doświadczenia winna przebiegać drogą indukcji arystotelesowskiej, której jakby przedłużeniem jest redukcja.

6 Por. Z. J. Zdybicka, o konieczną dla etyki filozofię człowieka, „Znak” 23 (1971) nr 202, s. 500-511. 
Doświadczenie może być sprowadzone do dwóch obszarów: doświadczenia istnienia siebie ( swojego „ja”, swojej jaźni, ,ja” jako podmiotu) i doświadczenia swojego działania (dynamizmu, aktywności). Obydwa te obszary ściśle się przenikają i są nierozdzielne. Obszar doświadczenia dotyczącego dynamizmu człowieka znalazł szerokie rozwinięcie w filozoficznej refleksji Wojtyły. Całe studium Osoba i czyn może być uznane za wnikliwą prezentację podstawowego przedmiotu doświadczenia człowieka, jakim jest ludzki dynamizm. Integralnie ujęty dynamizm człowieka ujawnia się w dwojaki sposób: poprzez działanie (człowiek działa) oraz dzianie się (coś dzieje się w człowieku). W tych dwóch postaciach dynamizmu ukazuje się aktywność, zwana czynnością, oraz bierność, zwana pasywnością (agere et pati) ${ }^{7}$. Czyn jest tą formą dynamizmu ludzkiego, która jest związana z wolnością i sprawczością. Wolność i sprawczość to zasadnicze czynniki będące podstawą odróżnienia czynów i uczynnień ${ }^{8}$.

W ludzkim czynie, według Wojtyły, następuje bezpośrednie doświadczenie swojego ,ja” jako podmiotu, który jest nam dany. Ludzkie operari odsłania ten podmiot. Podstawowym elementem ludzkiej podmiotowości jest świadomość. Objawia nam ją świadome działanie. Czyn jest świadomym działaniem. To dzięki świadomości człowiek nie tylko działa świadomie, ale ma świadomość tego, że działa i że działa świadomie ${ }^{9}$. Drugim konstytutywnym elementem podmiotowości osoby jest sprawczość. „Ja” jest nie tylko świadome siebie, nie tylko przeżywa siebie jako podmiot, ale ma moc sprawiania czynu.

\section{Fenomenologia transcendencji}

Greckie słowo phainomenōn oznacza to, co się jawi, ukazuje. Fenomenologia „zamyka” historię filozofii nowożytnej, a „otwiera” okres filozofii współczesnej ${ }^{10}$. Procedura fenomenologiczna polega na rozjaśnianiu

Por. K. Wojtyła, Osoba i czyn, Kraków 1969, s. 62-63.

K. Wojtyła, Osoba i czyn, dz. cyt., s. 68.

K. Wojtyła, Osoba i czyn, dz. cyt., s. 33.

10 Por. A. Sikora, Spotkania z filozofią od Heraklita do Husserla, Warszawa 2009, s. 186. 
w oglądzie, określaniu sensu i rozróżnianiu sensu. Fenomenologia porównuje, łączy, wyznacza odniesienia, dzieli na części albo wyodrębnia momenty. Jest badaniem esencji i według niej wszystkie problemy sprowadzają się do określenia istoty: na przykład istoty percepcji przy jednoczesnym odrzuceniu wszelkich przedzałożeń ${ }^{11}$. Fenomenologia jako poszukiwanie istoty otwiera na refleksję, dialog i wolną od uprzedzeń i założeń wstępnych próbę zrozumienia świata, doświadczania siebie i drugiego człowieka.

Kardynał Karol Wojtyła wyróżnia kilka znaczeń terminu „transcendencja”. Na pierwszym planie wymienia znaczenie związane z metafizyką i teorią poznania ${ }^{12}$. Pierwsze znaczenie wyraża się w tzw. transcendentaliach, które zawierają najbardziej ogólne określenia rzeczywistości, takie jak: byt, prawda, dobro, piękno. Każde z tych określeń przekracza swoją treścią wszelkie gatunki oraz rodzaje, wedle których ujmujemy i określamy przedmioty znanej nam rzeczywistości. Drugie, teoriopoznawcze znaczenie transcendencji wskazuje na znamienne dla aktów ludzkiego poznania przekraczanie podmiotu, na wychodzenie poza podmiot poznający w kierunku przedmiotu. Ten rodzaj transcendencji Wojtyła nazywa transcendencją poziomą. W jej zakres włącza także akty wolitywne, poprzez które człowiek również przekracza siebie w kierunku rzeczywistości zewnętrznych. Zatem transcendencja pozioma, o której mówi Wojtyła, ma dwa wymiary: jest to transcendencja poznawcza i wolitywna. Wprawdzie w inny sposób dokonuje się przekraczanie granic podmiotu w aktach poznawczych, a w inny w aktach chcenia, czyli aktach dążeniowych, ale i w jednym, i drugim przypadku następuje przekroczenie podmiotu - poprzez te akty intencjonalne w stronę przedmiotu ${ }^{13}$.

Oprócz transcendencji poziomej Wojtyła w dziele Osoba i czyn wyróżnił transcendencję pionową. Jest to transcendencja istniejąca przez sam fakt wolności (samostanowienia), bycia wolnym w działaniu - a nie tylko przez intencjonalne skierowanie aktów poznawczych czy też chceń w stronę jakiegoś przedmiotu. Na innym miejscu Wojtyła określa ten

11 Por. E. Husserl, Idea fenomenologii, tłum. J. Sidorek, Warszawa 2008, s. 23.

12 Por. K. Wojtyła, Osoba i czyn, dz. cyt., s. 187-188.

13 Por. K. Wojtyła, Osoba i czyn, dz. cyt., s. 109. 
rodzaj transcendencji jako nadrzędność ,ja” w stosunku do swoich czynów, a także zależność ,ja” od samego siebie i od prawdy ${ }^{14}$.

Oprócz transcendencji pionowej w porządku wolitywnym zdaje się mówić o transcendencji pionowej w porządku poznawczym. Wyraża się ona w fakcie nadrzędności ,ja” w stosunku do przedmiotów poznania. Wyższość tę zawdzięcza prawdzie i dynamicznemu do niej odniesieniu. Te obie transcendencje pionowe, w porządku poznawczym i wolitywnym, Wojtyła uważa za szczególne signum distinctivum bytu ludzkiego.

\section{Transcendencja w aktach poznania intelektualnego}

Wojtyła transcendencję poznawczą nazywa transcendencją poziomą i uważa ją za drugorzędną w stosunku do transcendencji pionowej, która ujawnia się przede wszystkim w samostanowieniu. Niektóre jednak teksty upoważniają do wniosku, że transcendencja poznawcza zyskuje niekiedy wymiar transcendencji pionowej. Ta ostatnia przejawia się, jego zdaniem, w niezależności i wyższości osoby wobec świata przedmiotów poznania. Tę wyższość osoba ma dzięki prawdzie i dynamicznemu do niej odniesieniu ${ }^{15}$.

Transcendencja poznawcza w pismach Wojtyły prezentuje się skromnie. W swoim dziele myślowym, pozostawionym w publikacjach, najmocniej zafascynował się sprawą ludzkiego czynu. Zwrócił w pewnej mierze uwagę na rozumność i świadomość czynu, jednakże najwięcej miejsca poświęcił zagadnieniu wolnego sprawstwa. Znalazło to konkretny wyraz w szerokim omawianiu sprawczości i samostanowienia. Passusy o poznaniu pojawiają się najczęściej przy przedstawianiu uwarunkowań wolnego wyboru człowieka, przy omawianiu motywacji chcenia, a także przy rozważaniach na temat sumienia. Kluczowe miejsce w tej prezentacji zajmuje prawda o dobru, która jest dziełem intelektu poznającego. Fundamentalnym elementem poznawczej transcendencji osoby w ujęciu Wojtyły jest zdolność umysłu do ujmowania prawdy o rzeczywistości,

14 Por. K. Wojtyła, Osoba i czyn, dz. cyt., s. 162.

15 Por. K. Wojtyła, Osoba i czyn, dz. cyt., s. 150, 153, 188. 
szczególnie zaś prawdy o dobru, prawdy o przedmiotach jako wartości, jako dobru ${ }^{16}$. Ta prawda o dobru ujawnia się w funkcjonowaniu ludzkiego sumienia ${ }^{17}$. Rodzi ona powinność, przez co wskazuje na zależność dobra od prawdy. Przeżywana powinność staje się warunkiem zaistnienia odpowiedzialności ${ }^{18}$. Krakowskiemu kardynałowi nie chodziło o uniesprzecznienie faktu poznania, ale jedynie o ujaśnienie tej czynności w kontekście opisywania spełniania się ludzkiej wolności. Podobnie ma się rzecz z prezentacją ludzkiej miłości jako drugiej ważnej formy transcendencji człowieka.

\section{Transcendencja przez miłość}

U Wojtyły wszystkie elementy przynależące do indywidualnej (upodobanie, pożądliwość, życzliwość), jak i wspólnotowej (wzajemna sympatia i przyjaźń) struktury miłości jednoczą się i znajdują swój najpełniejszy wyraz na płaszczyźnie miłości oblubieńczej. Stanowi ona poniekąd ich syntezę, choć o wielokroć swoim wymiarem je przekraczającą. Najwłaściwszym miejscem wypracowania owego wzajemnego oddania, właściwego dla miłości oblubieńczej, jest małżeńska i rodzinna komunia osób (communio personarum). Jako taka stanowi ona układ, do którego wchodzi się najbardziej wolnym aktem, na zasadzie dobrowolnego wyboru ${ }^{19}$.

Rozważania Wojtyły o miłości mają charakter psychologiczno-etyczny i są prowadzone w zasadzie metodą fenomenologiczną. Stosują tę metodę, bazując także, w dużej mierze, na tradycji tomistycznej. ukazał najpierw warstwy (odmiany, stopnie) miłości, tak w wymiarze indywidualnym, jak

16 Por. E. Kaczyński, „Prawda o dobru” w koncepcji moralności kard. K. Wojtyły, „Roczniki Filozoficzne" 28 (1980) z. 2, s. 60.

17 Por. Z. J. Zdybicka, Autonomia sumienia a nakazy religijne, „Roczniki Filozoficzne” 28 (1980) z. 2, s. 119-124.

18 Por. T. Styczeń, Ja w świetle swego sądu: powinienem, „Roczniki Filozoficzne” 28 (1980) z. 2, s. 148-154.

19 Por. K. Wojtyła, Miłość i odpowiedzialność. Studium etyczne, Lublin 1982, s. 90-91. 
i wspólnotowym ${ }^{20}$. W związku z tym znajdujemy w jego rozważaniach ciekawe analizy na temat miłości jako upodobania, pożądania, życzliwości, sympatii, wzajemności, przyjaźni, miłości oblubieńczej. W tej ostatniej postaci szczególnie rozwinął myśl o miłości jako bezinteresownym darze. Dział rozważań poświęconych tym tematom nazywa analizą metafizyczną miłości. Owo nazwanie nie jest zbyt precyzyjne, jako że znajdujemy w tych rozważaniach sporo informacji z zakresu psychologii. Analizę metafizyczną miłości dopełnia analizą psychologiczną i etycz$n a^{21}$. Charakterystyczny dla tych analiz jest fakt, że nie poprzestaje jedynie na opisie miłości, ale także formułuje postulaty. Przechodzi w nich od elementów deskryptywnych do postulatywnych.

Cnota miłości, według Wojtyły stanowi rzeczywistość mocno zakorzenioną w duchowej głębi człowieka, poprzez związanie jej wewnętrznej treści z pierwiastkami wolności i prawdy. Jako taka charakteryzuje się afirmatywnym odniesieniem do wartości osoby jako osoby rozumnej, mającej właściwą dla siebie doskonałość duchową. Odnowienie to konstytuuje zintegrowaną osobowo postawę, z której wyrastają kolejne elementy tworzące miłość jako cnotę. Wśród nich koncentruje się szczególnie na rzeczywistości zjednoczenia i przynależności osób znajdujących jedną z form swego wyrazu osoby - współtwórcy miłości. Podkreśla ważność odpowiedzialności za sam wybór i za wybraną osobę. Wyraża również przekonanie, że zakotwiczona w wolności odpowiedzialność za drugą osobę ujawnia główną, szczęściotwórczą siłę cnoty miłości, która poprzez to wykazuje otwartość na wartości absolutne ${ }^{22}$. Owa wyjątkowa pozycja człowieka ujawniająca się w aktach osobowej miłości jest wynikiem faktu, że w miłości ludzkiej obecne są elementy poznania (prawdy) i wolności.

20 Por. K. Wojtyła, Miłość i odpowiedzialność. Studium etyczne, dz. cyt., s. 69.

21 K. Wojtyła, Miłość i odpowiedzialność. Studium etyczne, dz. cyt., s. 92-94.

22 K. Wojtyła, Miłość i odpowiedzialność. Studium etyczne, dz. cyt., s. 122. 


\section{Transcendencja wolitywna}

Wojtyła stwierdza, że wolność ludzkiego działania jest faktem podlegającym doświadczeniu. Terenem, na którym wolność jest dostrzegana, jest ludzki czyn. Stwierdzenie, że w doświadczeniu zawarte są istotne właściwości osoby i czynu, które należy stopniowo odsłaniać, doprowadziło kardynała do wniosku, iż należy określić wolność jako właściwość osoby zwaną samostanowieniem oraz jako właściwość woli - władzy, przez którą osoba urzeczywistnia samostanowienie. Pierwszy rodzaj wolności nazwał wolnością w znaczeniu podstawowym, drugi zaś wolnością w znaczeniu rozwiniętym. Dalszy proces eksplikacji doświadczenia wolności pozwolił kardynałowi odkryć te elementy struktury osoby, które wolne działanie warunkują, a są nimi samoposiadanie i samopanowanie. Należy tu podkreślić, że zarówno samostanowienie, jak i samoposiadanie oraz samoopanowanie nie są strukturami ontycznymi, ale są rzeczywistością zjawiskową ujmowaną w opisie fenomenologicznym.

Można powiedzieć, że samostanowienie uprzedmiatawia podmiot działający w jego działaniu. Owa obiektywizacja osoby nie jest jej reifikacją ${ }^{23}$. Właśnie w tym stanowieniu o sobie podmiotowość osoby objawia się w swych najgłębszych możliwościach, które świadczą o tym, co człowiecze (humanum) i zarazem osobowe ${ }^{24}$. To właśnie dzięki samostanowieniu następuje pełna akceptacja osoby, jej podmiotowości i przedmiotowości. Wskazuje bowiem na działający podmiot, a także przyczynia się do realizacji siebie ${ }^{25}$.

Owa koncepcja samostanowienia człowieka prezentowana przez Wojtyłę przypomina do pewnego stopnia koncepcję szczęścia Władysława Tatarkiewicza i koncepcje scholastyczne. Według nich człowiek, aby był szczęśliwy, nie może szczęścia uczynić celem swojego działania. Trzeba je osiągnąć przez spełnianie obowiązków i realizację dobra. Podobnie jest w spełnianiu siebie. Człowiek, dążąc do przedmiotu, realizując jakieś

23 Por. K. Wojtyła, Osobowa struktura samostanowienia, „Roczniki Filozoficzne” 29 (1981) z. 2, s. 9.

24 Por. K. Wojtyła, Osobowa struktura samostanowienia, dz. cyt., s. 9.

25 Por. I. Dec, Niektóre dawniejsze i współczesne próby rozumienia osoby $w$ „,filozofii chrześcijańskiej”, „Communio” 3 (1983) nr 2, s. 120. 
dobro, staje się zarazem przedmiotem zmieniającym się pod wpływem tego działania ${ }^{26}$.

Uprzedmiotowienie dokonuje się wraz z upodmiotowieniem, dlatego, że każde uprzedmiotowienie jest warunkowane świadomością: , człowiek przecież przeżywa każde swoje chcę, każde samostanowienie, jako fakt podmiotowy"27. Świadomość jednakże nie kieruje wolą. Kieruje nią poznanie: nihil volitum nisi preacognitum. Poznanie, samowiedza ma z kolei charakter obiektywizujący. Tak więc subiektywizacja i obiektywizacja, „uprzedmiotowienie i upodmiotowienie wzajemnie się dopełniają i niejako równoważą"28. Tu właśnie podkreślony jest realizm samostanowienia. Poznanie pozwala wyjść poza subiektywność. Poznanie, kierujące chceniem i samostanowieniem, jest przekreśleniem solipsyzmu, subiektywizmu i idealizmu. W działaniu świadomym istnieje więc jedność samostanowienia i świadomości, czy też w innym wymiarze przedmiotowości i podmiotowości człowieka. Osoba stanowi jedność i w niej się spełnia ${ }^{29}$.

Drugi rodzaj wolności: wolność w znaczeniu rozwiniętym dotyczy wolności wyboru. Wolność ta ujawnia się przede wszystkim w rozstrzyganiu i wybieraniu. Oznacza ona wolność dystansowania się od poszczególnych przedmiotów i ich przedstawień. Tym, co szczególnie charakteryzuje wolność, w znaczeniu rozwiniętym, jest zdolność wyboru wartości na podstawie prawdy o przedmiocie. Wolność ludzka to „wolność do przedmiotów - wartości” oraz samozależność od prawdy. Zależność od własnego „ja” jest, zdaniem Wojtyły, podstawą wolności $^{30}$. Ta samozależność idzie w parze z samostanowieniem. „Aby być wolnym, trzeba stanowić konkretne ,ja”, będące dla siebie samego przedmiotem" ${ }^{31}$.

26 Por. J. Gałkowski, Samostanowienie osoby w ujęciu kardynała Karola Wojtyły, „Zeszyty Naukowe KUL" 22 (1979) nr 1-3, s. 78.

27 K. Wojtyła, Osoba i czyn, dz. cyt., s.117.

${ }_{28}$ K. Wojtyła, Osoba i czyn, dz. cyt., s. 119.

29 Por. J. Gałkowski, Samostanowienie osoby..., dz. cyt., s.79.

30 Por. K. Wojtyła, Osoba i czyn, dz. cyt., s. 122.

31 Por. K. Wojtyła, Osoba i czyn, dz. cyt., s. 124. 
Dla tak odczytanej wolności Wojtyła nie szuka zasadniczo źródła w strukturze ontycznej osoby. Mówi natomiast, że jest ona objawem duchowości człowieka. Sama duchowość nie może być określona tylko jako przeciwstawienie materialności, ale jest „widoczna” i objawia się przede wszystkim przez wolność osoby ludzkiej. Wolność w ujęciu Wojtyły stanowi faktycznie istotną, szczególnie czytelną właściwość osoby ludzkiej decydującą o jej transcendencji.

„Chodzi tu nie tylko o duchowość jako zespół przejawów, które stanowią o transcendencji osoby w czynie, ale chodzi o realne źródło bytu"32. Wojtyła stwierdza tu wyraźnie, że o jedności ludzkiego bytu stanowi pierwiastek duchowy. W swoich rozważaniach nie podjął jednak metafizycznych analiz ludzkiego ducha i jego związku z ciałem. Nie wnikał w jego naturę i strukturę, ale zatrzymał się na samym stwierdzeniu jego obecności. Swoje analizy poświęcał przede wszystkim opisowi przejawów ludzkiego ducha i całego człowieka. Stąd też w dziele Osoba i czyn dotyka problemu ludzkiego ducha, ale oznajmia zarazem, że jest to droga już przetarta, dlatego z niej rezygnuje, chociaż ją akceptuje i raz po raz na nią wskazuje ${ }^{33}$.

\section{Zakończenie}

Transcendencję osoby w myśli Karola Wojtyły można nazwać transcendencją fenomenologiczną, bowiem Wojtyła zatrzymał się w zasadzie tylko na opisie strony zjawiskowej transcendencji, badając sposoby jej ujawniania się. W rozważaniach nie znajdziemy na ogół odniesień osoby do innych bytów przyrodniczych, ale cała refleksja nad człowiekiem zamyka się w obrębie jego samego. Stąd można powiedzieć o transcendencji osoby w czynie, transcendencji osoby wobec własnego dynamizmu. Transcendencja ta, ukazana w niniejszym artykule na podstawie myśli Wojtyły, sprawia, że nie można człowieka zredukować tylko do wymiaru wegetatywno-emotywnego. Klasyczna bowiem definicja człowieka jako

32 Por. K. Wojtyła, Osoba i czyn, dz. cyt., s. 195-196.

33 Por. K. Wojtyła, Osoba i czyn, dz. cyt., s. 195-196. 
animal rationale implikowała takie przekonanie. Oparta na niej filozofia traktowała człowieka przedmiotowo. $Z$ drugiej jednak strony równie stare jak poprzednie jest przekonanie o jego pierwotnej oryginalności. Cała przecież sfera świadomości, warunkowana przez samowiedzę, ponadto cała sfera miłości, przeżyć poznawczych, wolitywnych stanowią nieredukowalny aspekt osoby.

Niewątpliwym wkładem Wojtyły w ukazanie rysu transcendencji osoby jest fakt, że ogromnie poszerzył on prezentację przejawów transcendencji. Prawda o transcendencji osoby - bytu ludzkiego jest prawda o ogromnej wadze dla współczesnej filozofii i kultury. Stąd też godna jest ciągłego zgłębiania i stosowania jej w życiu. 


\section{Summary}

Transcendencja osoby ludzkiej w refleksji filozoficznej kardynała Karola Wojtyły

Artykuł przedstawia koncepcje transcendencji osoby wypracowaną przez Karola Wojtyłę. Wyraża się w niej wyższość ludzkiego działania nad aktywnością innych istot. Według Wojtyły przejawia się ona w spełnianiu wolnych duchowych aktów poznawczych i pożądawczych. Opis transcendencji akcentuje fenomenologię czynu ludzkiego jako czynu poznawczego i wolitywnego. Ostateczną, wewnętrzną racją transcendencji osoby według Wojtyły jest jej duchowość.

Słowa kluczowe: transcendencja, osoba ludzka, fenomenologia, kardynał Karol Wojtyła

\section{The transcendence of the human person in the philosophical reflection} of cardinal Karol Wojtyla

In the article the concept of the transcendence of the human person worked out by cardinal Karol Wojtyla is presented. The supremacy of human activity over activity of other beings is expressed in it. It manifests itself, according to Karol Wojtyla, in performing free, spiritual cognitive and appetitive acts. The description of transcendence accentuates the phenomenology of the human act as a cognitive and volitional act. The ultimate internal rationality of the person's transcendence is, according to Wojtyla, their spirituality.

Keywords: transcendence, the human person, phenomenology, cardinal Karol Wojtyla

\section{Bibliografia}

Dec I., Niektóre dawniejsze i wspótczesne próby rozumienia osoby w „, filozofii chrześcijańskiej”, „Communio” 3 (1983) nr 2, s. 120-138.

Gałkowski J., Samostanowienie osoby w ujęciu kardynała Karola Wojtyły, „Zeszyty Naukowe KUL" 22 (1979) nr 1-3, s. 73-79.

Husserl E., Idea fenomenologii, tłum. J. Sidorek, Warszawa 2008.

Kaczyński E., „Prawda o dobru” w koncepcji moralności kard. K. Wojtyły, „Roczniki Filozoficzne" 28 (1980) z. 2, s. 47-71.

Krąpiec M., Człowiek. Kultura. Uniwersytet, Lublin 1982.

Kurdziałek M., Średniowieczne doktryny o człowieku jako obrazie świata, „Roczniki Filozoficzne" 19 (1971) z. 1, s. 5-39.

Sikora A., Spotkania z filozofia od Heraklita do Husserla, Warszawa 2009. 
Stępień A. B., Fenomenologia tomizująca w książce „Osoba i czyn”, „Analecta Cracoviensia" 5-6 (1973-1974), s. 153-157.

Styczeń T., Ja w świetle swego sądu: powinienem, „Roczniki Filozoficzne” 28 (1980) z. 2, s.148-154.

Wojtyła K., Miłość i odpowiedzialność. Studium etyczne, Lublin 1982

Wojtyła K., Osoba i czyn, Kraków 1969.

Wojtyła K., Osoba: podmiot i wspólnota, „Roczniki Filozoficzne” 24 (1976) z. 2, s. 5-40.

Wojtyła K., Osobowa struktura samostanowienia, „Roczniki Filozoficzne” 29 (1981) z. 2, s. 5-12.

Zdybicka Z. J., Autonomia sumienia a nakazy religijne, „Roczniki Filozoficzne” 28 (1980) z. 2, s. 119-124.

Zdybicka Z. J., O konieczna dla etyki filozofię człowieka, „Znak” 23 (1971) nr 4 (202), s. 500-511. 